\title{
ANALISIS PENGARUH KOMPETENSI GURU DALAM MENGHADAPI PEMBELAJARAN ERA MILENIAL TERHADAP HASIL BELAJAR SISWADI SMK PANCA BUDI 2 MEDAN TAHUN AJARAN 2019-2020
}

\author{
Suci Mahdaini Panjaitan \\ Ijah Mulyani Sihotang \\ Mahasiswa dan Dosen Prodi Pendidikan Akuntansi Universitas Muhammadiyah Sumatera Utara \\ Medan, Indonesia Jl. Kapten Mukhtar Basri No. 3 Medan 20238 \\ (Email: ijahmulyani@umsu.ac.id)
}

\begin{abstract}
Abstrak
Penelitian ini dilakukan di SMK Panca Budi 2 Medan, dengan tujuan untuk mengetahui apakah ada pengaruh kompetensi guru dalam menghadapi pembelajaran milenial terhadap hasil belajar akuntansi siswa kelas XI di SMK Panca Budi 2 Medan pada Tahun Ajaran 2019-2020 Mengembangkan mata pelajaran berbasis blended sejalan dengan tantangan teknologi, strategi belajar, cara komunikasi baru, dan penilaian. Berarti pendidik di era informasi ini memiliki kecenderungan untuk gaya belajar aktif, sekuensial, penginderaan, dan visual. Teknik pengambilan sampel dalam penelitian ini menggunakan total sampling dimana jumlah sampel sama dengan total populasi 45 orang. Dari hasil analisis data, diperoleh hasil 99,6\% dari variabel independen (Kompetensi Guru dalam menghadapi pembelajaran milenial) mempengaruhi variabel dependen (Hasil Belajar Siswa). Proses pembelajaran dan hasil belajar siswa tidak hanya ditentukan oleh sekolah, pola, struktur dan isi kurikulum, tetapi sebagian besar ditentukan oleh kompetensi guru yang mengajar dan membimbing siswa di sekolah. Dalam konteks ini Blended learning dapat menjadi salah satu perkembangan pembelajaran paling signifikan di era milenium.
\end{abstract}

Kata kunci: Era Milenial, Kompetensi Guru, Blended Learning

\begin{abstract}
This research was carried out at SMK Panca Budi 2 Medan, with the aim of finding out whether there was an influence of teacher competence in facing millennial learning towards the accounting learning outcomes of class XI students at SMK Panca Budi 2 Medan in Academic Year 2019-2020. Developing blended learning-based subjects in line with the unique challenges of technology, learning strategies, new ways of communicating, and assessments. Means that educators in this information age have a tendency for active learning styles, sequential, sensing, and visual. The sampling technique in this study uses total sampling where the number of samples is equal to the total population of 45 people. From the results of data analysis, the results obtained 99.6\% of the independent variables (Teacher Competence in facing millennial learning) affect the dependent variable (Student Learning Outcomes). The learning process and student learning outcomes are not only determined by the school, the pattern, structure and content of the curriculum, but are largely determined by the competence of the teacher who teaches and membing students at school. In this context Blended learning can be one of the most significant learning developments in the millennial era.
\end{abstract}

Keywords: Millennial Era, Teacher Competence, Blended Learning 


\section{Pendahuluan}

Era milenial menyebabkan ilmu pengetahuan dan teknologi (iptek) berkembang sangat pesat, bahkan sepak terjang kehidupan dunia pendidikan juga senantiasa mengalami perubahan. Di era generasi $\mathrm{Z}$ atau Net Generation, jika dunia pendidikan tidak berusaha untuk memperbaiki sistem pembelajaran maka akan membentuk kesenjangan antar pendidik dengan peserta didiknya.

Seyogyanya membelajarkan anak milenial akan menjadi sangat sulit jika pendidik masih menerapkan gaya masa lalu, yaitu membiarkan peserta didik untuk terus mencatat pelajaran di papan tulis, atau bahkan tidak diberi ruang kebebasan untuk menyapaikan pendapat. Di era milenial saat ini sudah seharusnya guru menerapkan sistem pembelajaran student centered learning diiringi dengan kemajuan teknologi. Maka dari itu diperlukan inovasi dan kreativitas yang tinggi dalam mengajar anak milenial, karena mereka mempunyai konsep berpikir yang jauh berbeda. Dunia anak milenial bukan hanya kehidupan yang tampak secara kasat mata, tetapi juga yang jauh dijangkau oleh pandangan.

Melalui pergerakan hidup masyarakat yang semakin pesat serta melahirkan kecanggihan teknologi yang baru, menjadikan asal muasal munculnya pembelajaran era milenial dalam memenuhi tantangan era milenial sebagai inovasi baru. Pembelajaran yang sering dikerjakan secara tatap muka dengan bantuan $e$ learning adalah pembelajaran yang biasa dikenal dengan istilah era milenial. Upaya mencipatakan pelajar yang unggul dalam dunia pendidikan ialah tugas seorang guru. Untuk menciptakan seorang pendidik professional dan berkompeten adalah sebuah keunikan. Bahkan pekerjaan sebagai seorang pendidik sangat erat kaitannya dengan totalitas dalam mengajar, personaliti, bahkan identik dengan representasi kehidupan.

Untuk menciptakan sistem pembelajaran berbasis milenialsejalan dengan tantangan unik yang meliputi kecanggihan teknologi, strategi dalam kegiatan belajar dan mengajar, tata caramenyampaikan, dan pemecahan masalah. Dengan demikian guru di 
zaman era milenial ini mempunyai kecenderungan gaya belajar yang aktif, melalui media visual, pendekatan dengan peserta didik serta mampu membangkitkan minat siswa untuk belajar. Melalui kegiatan pengamatan dan tanya jawab dengan perwakilan guru bidang study akuntansi di Sekolah Menengah Kejuruan Panca Budi 2 Medan pada bulan Maret mengemukakanan bahwasanya aktivitas belajar dan mengajar yang digunakan di ruang kelas berpusat kepada guru dan belum mengarah kepada pembelajaran era milenial sehingga kemampuan siswa untuk berinteraksi langsung dengan teknologi masih kurang, minat siswa untuk mengikuti aktivitas pembelajaran terbilang rendah dan siswa masih sedikit yang termotivasi untuk belajar. Dengan demikian akan menyebabkan nilai atau hasil belajar siswa menurun.

\section{Kompetensi Guru}

Sebagai seorang makhluk sosial manusia adalah sosok yang mudah menerima perubahan, sejatinya seorang pendidik pantas untuk menyadari hal tersebut. Bahkan menjadi seorang guru yang berkompeten dalam profesinya, hendaklah membuka diri, menambah wawasan dan terus berkembang terhadap perkembangan zaman. Hopkins (2010:47) menyatakan bahwa, "kompetensi sangat terkait dengan keterampilan dan kecerdasan kognitif". Patut kiranya seorang guru mengikuti berbagai loka karya, kursus, pelatihan, agar kognitif dan kekinian guru tetap terjaga.

Kepercayaan diri juga sangat dibutuhkan oleh seorang guru selain empat pilar kompetensi yang wajib dijunjung tinggi. Dua hal yang saling berkendalian baik kompetensi maupun kepercayaan diri pada seorang. Kepercayaan diri adalah kemampuan afektif atau kualitas emosional. Melalukan percobaan terhadap ide-ide baru membuat manusia, termasuk guru menjadi lebih kompeten dalam menggunakan kemampuan yang dia miliki”. Oleh karena itu, meyakinkan seorang guru untuk pindah dari perlakuan yang telah usang lalu mencoba pembelajaran yang modern dan kekinian merupakan hal paling utama. 
Proses kegiatan membelajarkan peserta didik adalah pilar utama untuk meningkatan kualitas pendidikan, dengan berbagai kompetensi yang dimiliki oleh seorang guru wajib bagi seorang pendidik untuk terus mengasah ilmu yang dimlikinya. Sehingga guru dapat menempatkan berbagai kompetensi yang dimilikinya sesuai dengan aktivitas pembelajaran di dalam kelas .

\section{Pembelajran Era Milenial}

Johan (2010) mengemukakan pendapat bahwa "Information and Communication Of Technology (ICT) dalam waktu yang sangat singkat telah menjadi satu bahan bangunan penting dalam perkembangan kehidupan masyarakat modern". Berbagai Negara di belahan dunia merasa bahwa bagian pokok dari pendidikan adalah sejajar dengan membaca, menulis dan numerasi sama halnya degan memahami ICT, menguasai keterampilan dasar ICT serta memiliki konsep ICT. UNESCO mengatakan, "suatu negara perlu mendapatkan akses ICT dan menyediakan fasilitas pendidikan yang terbaik, baik di negara modern maupun negara tetinggal, dengan demikian, kaula muda siap berperan penuh dalam masyarakat modern dan mampu berperan dalam negara maju".

$$
\text { Kusairi }
$$

mengungkapkan bahwa "perkembangan Information and Communication Of Technology (ICT) yang memiliki banyak manfaat ini belum dimanfaatkan secara optimum dalam proses pembelajaran”. Upaya ini perlu mengintegrasikan ICT kedalam proses pembelajaran.

\section{Bagi pengajar penggunaan ICT} akan menghasilkan nilai kebaikan dan keefisensian dalam pembelajaran. Bagi peserta didik, dengan menggunakan tenologi informasi akan membuat siswa menjadi lebih leluasa dalam belajar. Siswa lebih untuk mengakses pelajaran yang diberikan oleh guru tanpa batasan ruang dan waktu.

Abdullah (2011), menyatakan bahwa "terdapat beragam pandangan mengenai model pemanfaatan ICT dalam pendidikan, di antaranya sebagai berikut: pertama, ICT sebagai media (alat bantu) pendidikan, artinya hanya sebagai pelengkap untuk memperjelas uraian-uraian yang 
disampaikan pengajar, kedua ICT sebagai sumber pada jenis pemanfaatan kategori ini, ICT digunakan sebagai sumber informasi, dalam penggunaannya peserta didik mencari informasi via ICT berdasarkan bimbingan pengajar, ketiga ICT sebagai sistem pembelajaran, pada pernyataan ini information and Communication of Technology (ICT) dirancang sedemikian rupa sebagai suatu sistem pembelajaran yang terintegrasi”. (Abdullah, D. 2011)

Indriyani (2007) menyatakan bahwa, "praktek di lapangan, dalam tataran empiris praktis menunjukkan bahwa beberapa Perguruan tinggi menyelenggarakan kegiatan $e$ learning sebagai suplemen (tambahan) terhadap materi pelajaran yang disajikan secara reguler di kelas".

Pembelajaran berbasis blended learning bisa diterapkan dimana saja, kapan saja dan oleh siapa saja, terutama bagi mereka yang memiliki mobilitas tinggi dan sulit untuk terus bertatap muka secara langsung dengan pendidik. Sebagai sarana belajar bersama adalah alasan lain bagi mereka yang merasa membutuhkan materi tambahan. Banyak pelajar merasa tidak nyaman dengan pembelajaran yang terpusat kepada guru, padahal dengan blended learning mereka bisa dengan mudah mendapatkan kajian baru yang lebih terkini dari berbagai sumber bahkan pakar dari seluruh belahan dunia. Generasi $\mathrm{Z}$ sudah sangat dimanjakan sekali dengan berbagai kemudahankemudahan yang ditawarkan. Tidak zamannya lagi kita harus berdiam diri menunggu intruksi dari pendidik saja di sekolah.

Mengaplikasikan google clasroom tentunya bukan hal mudah bagi guru yang tidak memiliki kemampuan di bidang teknologi informasi. Namun sesungguhnya mengaplikasikan google classroom dapat dipelajari dengan memperhatikan langkah-langkah berikut ini :

1) Bukawebsite googlekemudian masuk pada laman google classroom

2) Pastikan Anda memiliki akun Google Apps for Education. Kunjungi classroom.google.com dan masuk. Pilih apakah Anda 
seorang guru atau siswa, lalu buat kelas atau gabung ke kelas.

3) Jika Anda administrator Google Apps, Anda dapat menemukan informasi lebih lanjut tentang cara mengaktifkan dan menonaktifkan layanan di Akses ke Kelas.

4) Guru dapat menambahkan siswa secara langsung atau berbagi kode dengan kelasnya untuk bergabung. Hal ini berarti sebelumnyaguru di dalam kelas nyata (di sekolah) sudah memberitahukan kepada siswa bahwa guru akan menerapkan google clasroomdengan syarat setiap siswa harus memiliki email pribadi dengan menggunakan nama lengkap pemiliknya (tidak menggunakan nama panggilan/samaran).

5) Guru memberikan tugas mandiri atau melemparkan forum diskusi melalui laman tugas atau laman diskusi kemudian semua materi kelas disimpan secara otomatis ke dalam folderdi google drive.

6) Selain memberikan tugas, guru juga dapat menyampaikan pengumuman atau informasi terkait dengan mata pelajaran yang akan dipelajari oleh siswa di kelas nyata pada laman tersebut.Siswa dapat bertanya kepada guru ataupun kepada siswa lain dalam kelas tersebut terkait dengan informasi yang disampaikan oleh guru.

7) Siswa dapat melacak setiap tugas yang hampir mendekati batas waktu pengumpulan di laman Tugas, dan mulai mengerjakannya cukup dengan sekali klik.

8) Guru dapat melihat dengan cepat siapa saja yang belum menyelesaikan tugas, serta memberikan masukan dan nilai langsung di Kelas.

Cara bergabung dengan kelas, guru memiliki 2 cara untuk bergabung dengan kelas :

1) Bergabung dengan kelas menggunakan kode kelas. Jika guru memberikan kode kelas, gunakan kode ini untuk menambahkan siswa ke kelas. Guru mungkin memberikan kode tersebut saat siswa berada di kelas atau mengirimkannya melalui email kepada siswa.

2) Menerima undangan dari guru. Jika guru mengirimi siswa 
undangan, siswa akan melihat Bergabung di kartu kelas di halaman beranda Classroom siswa.

\section{Aplikasi Google Classroom} dapat digunakan oleh siapa saja yang tergabung dengan kelas tersebut. Kelas tersebut adalah kelas yang didesain oleh guru yang sesuai dengan kelas sesungguhnya atau kelas nyata di sekolah.

\section{Hasil Belajar}

Hasil belajar adalah kemampuankemampuan yang dimiliki siswa setelah ia menerima pengalaman belajarnya". Hasil belajar merupakan kemampuan yang diperoleh individu setelah proses belajar berlangsung, yang dapat memberikan perubahan tingkah laku baik pengetahuan, pemahaman, sikap dan keterampilan siswa sehingga menjadi lebih baik dari sebelumnya. Ranah perubahan kognitif, efektif dan psikomotorik itu mengarah pada taxonomy bloom tujuan pengajaran yang dikembangkan oleh Bloom.

\section{A. Metode Penelitian}

Penelitian ini dilakukan di Sekolah Menengah Kejuruan (SMK) Swasta Panca Budi 2 Medan yang beralamat di Jl. Gatot Subroto (GATSU) KM. 4,5 Medan, Simpang Tanjung, Kec. Medan Sunggal, Kota Medan Prov. Sumatera Utara.

\section{Populasi dan Sampel Penelitian}

Populasi dalam penelitian ini adalah seluruh guru Akuntansi di SMK Swasta Panca Budi 2 Medan yang berjumlah 45 orang. penelitian ini menggunakan jumlah sampel dengan 45 orang guru.

\section{Variabel Penelitian}

Variabel penelitian yang digunakan dalam penelitian ini adalah Variabel Bebas independent variable (X) dan Variabel Terikat/ dependent variable (Y). "Kompetensi Guru dalam menghadapi pembelajaran era milenial bertindak sebagai Variabel Bebas/ independent variable $(\mathrm{X})$ dan Hasil Belajar Siswa bertindak sebagai Variabel Terikat/ dependent variable (Y).

\section{Instrumen Penelitian}

Sumber data yang dipakai dalam penelitian ini adalah data primer, karena data diambil langsung dari responden penelitian. Data tersebut 
meliputi data kompetensi guru dalam menghadapi pembelajaran era milenial, komitmen mengajar guru, efektivitas kegiatan belajar mengajar, dan evaluasi kbm oleh masing-masing responden penelitian. Instrumen yang diapakai dalam penelitian ini meliputi dengan questioner serta tes hasil belajar.

\section{Hasil Penelitian Dan Pembahasan}

Peneliti memberikan angket sebanyak dua kali yaitu pada angket pengaruh kompetensi guru dalam menghadapi pembelajaran era milenial terhadap hasil belajar siswa yang dilakukan di XI SMA IT Alfityan School Medan untuk menguji validitas, sementara pengujian reliabilitas dilakukan di SMK Panca Budi 2 Medan.

Angket awalnya diuji cobakan dulu kepada 45 orang guru SMA IT Alfityan School Medan yang di duga memiliki karakteristik sama dengan sampel penelitian. Tes uji coba angket ini digunakan untuk melihat tingkat validitas angket yang telah dibuat oleh peneliti.
Seyognya penelitian ini memiliki tujuan untuk menguji antar variabel bebas dengan variabel terikat. Instrumen yang digunakan oleh peneliti dalam melakukan penelitian ini menggunakan angket sebagai alat untuk menilai pengaruh kompetensi guru dalam menghadapi pembelajaran era milenial terhadap hasil belajar siswa kelas XI akuntansi. Dan jumlah populasi terdiri dari 45 guru yang sudah merupakan perwakilan dari jumlah sampel dalam peneitian ini.

Secara umum, ada tiga tugas guru sebagai profesi, yakni mendidik, mengajar, dan melatih. Mendidik berarti meneruskan dan mengembangkan nilai-nilai hidup; mengajar berarti meneruskan dan mengembangkan ilmu pengetahuan; melatih berarti mengembangkan keterampilan-keterampilan untuk kehidupan siswa. Untuk dapat melaksanakan tugas dan tanggung jawab diatas, seorang guru dituntut memiliki beberapa kemampuan dan kompetensi tertentu sebagai bagian dan profesionalisme guru.

Sebelum dilakukan penelitian, kuesioner sebagai alat pendukung suatu penelitian terlebih dahulu diuji 
coba. Angket yang diuji untuk variabel kompetensi guru dan hasil belajar sebanyak 20 butir dilakukan dengan product moment dan cronbach alpha dengan menggunakan SPSS 22.

Melalui hasil perincian uji validitas angket kompetensi guru dan hasil belajar siswa, ternyata 2 butir angket hasilnya tidak valid, maka untuk tahap selanjutnya sebagai uji reliabilitas hanya 18 butir angket. Setelah data diuji coba dengan uji validitas dan reliabilitas maka tahap selanjutnya peneliti melakukan kembali pengujian terhadap data untuk meilihat pengaruh variabel bebas terhadap variabel terikat. Berdasarkan output SPSS tersebut, diketahui bahwa nilai signifikansi Asiymp.Sig (2-tailed) sebesar 0,085 lebih besar dari 0,05. Maka sesuai dengan dasar pengambila keputusan dalam uji normalitas kolmogrovsmirnov di atas, dapat disimpulkan bahwa data tersebut berdistribusi normal.

Dengan menggunakan uji hipotesis ternyata taraf nilai $t_{\text {hitung }}$ variabel kompetensi guru sebesar 108,63. Dan $\mathrm{t}_{\text {tabel }}$ melalui taraf signifikan $95 \%$ memiliki nilai 2,016 sehingga diperoleh data bahwa $t_{\text {hitung }}>t_{\text {tabel }}$. Berdasarkan analisis data maka variabel Kompetensi Guru dalam menghadapi pembelajaran era milenial (X) berpengaruh positif terhadap variabel hasil belajar siswa di SMK Panca Budi 2 Medan (Y) Tahun Ajaran 2019-2020. Dengan hasil data yang telah dilakukan analisis, maka memunculkan sebuah paradigma baru bahwa kompetensi guru sangat berpengaruh terhadap hasi belajar siswa. Jika seorang guru tidak memiliki kompetensi dalam membelajarkan anak didiknya, hasilnya seorang siswa akan merasa jenuh dalam menghadapi sebuah pembelajaran yang diberikan oleh guru. Dan siswa tidak memiliki keberanian untuk menyampaikan pendapatnya, siswa tidak bisa menjalin kerja sama antar teman sekelasnya, dan prestasi belajar siswa tetap pada presentase menurun.

Kompetensi guru merupakan salah satu faktor yang mempengaruhi terjadinya tujuan pembelajaran dan pendidikan di sekolah, proses belajar dan hasil belajar para siswa bukan saja ditentukan oleh sekolah, pola, 
struktur dan isi kurikulumnya, akan tetapi sebagian besar ditentukan oleh kompetensi guru yang mengajar dan membing mereka.

Berdasarkan hasil anaisis data diatas, sesungguhnya pembelajaran era milenial dapat menggeser pola kegiatan belajar mengajar tradisional menuju pembelajaran kekinian. Belajar di era milenial ini sejatinya bersifat saling melengkapi, kekurangan yang terjadi lewat pembelajaran face to face disempurnakan dengan adanya $e$ learning. Dengan pembelajaran tatap muka guru dapat memfungsikan kompetensi yang ada pada dirinya sebagai seorang pendidik, guru dapat bersentuhan secara langsung untuk melihat karakter siswanya, sehingga kedekatan sosial antar guru dan siswa dapat terjalin satu sama lain. Serta guru dapat memberikan motivasi secara langsung dan ekspresif kepada pelajar. Dengan adanya pembelajaran era milenial membuat aktivitas belajar siswa di dalam kelas menjadi lebih bervrisi. Siswa tidak lagi berfokus pada satu sumber melainkan ada banyak hal yang dapat dijadikan siswa untuk sumber belajar. Siswa akan lebih mudah menjelajahi materi pembelajaran yang disukai sesuai minat dan bakatnya, bahkan jika siswa malu untuk bertanya kepada guru pada saat proses pembelajaran siswa dapat melakukan diskusi belajar dengan guru melalui google classroom.

Kemajuan iptek di era milenial sebenarnya jauh lebih efektif untuk meningkatkan kualitas pembelajaran, karena sistemnya yang universal hal ini menjadikan pengetahuan siswa lebih mendunia, siswa tidak lagi kekurangan informasi yang terjadi dalam dunia pendidikan, bahkan siswa akan lebih mudah untuk bersaing dengan pelajar dibelahan bumi manapun. Semua ini akan terlaksana jika kurikulum pembelajaran dapat di integrasikan kepada setiap lembaga pendidikan. Oleh karena itu, peran guru sebagai sutradara menjadi sangat penting dalam membuat skenario proses pembelajaran.

Melalui pembelajaran era milenial ini diharapkan proses pembelajaran dapat terjadi bukan sekedar bertatap muka saja, namun adanya perubahan waktu pada saat kegiatan belajar 
Liabilities Jurnal Pendidikan Akuntansi

e-ISSN 2620-5866

Volume 2. No.3 Desember 2019 (201-212)

Doi 10.30596/liabilities.v2i3.3689

mengajar dengan menggunakan sistem virtual. Sehingga hal ini dapat mempermudah dan mempercepat akses pengajar dengan pendidik, adanya proses percepatan pengajaran, dengan demikian kreativitas dan inovasi antar guru dan siswa dituntut untuk lebih gesit.

Dan tujuan akhirnya, pembelajaran era milenial berupaya untuk mengajak kepada dunia pendidikan agar tidak terjebak dalam situasi yang keliru, yaitu menghasilkan manusia siap kerja, laku dalam pangsa pasar ketenagakerjaan. Dunia pendidikan sejatinya harus mampu mencetak sumber daya manusia yang berakhlak mulia serta unggul dalam pengetahuan dan keterampilan, sehat jasmani dan rohani bahkan mampu berkompeten secara nyata dengan dunia luar dikalangan pelajar.

\section{KESIMPULAN DAN SARAN}

\section{Kesimpulan}

Melalui penelitian dan pembahasan yang sudah dilakukan atas judul penelitian kompetensi guru dalam menghadapi pembelajaran era milenial terhadap hasil belajar siswa kelas XI di SMK Panca Budi 2
Medan Tahun Ajaran 2019-202, kesimpulannya adalah berikut ini :

1. Melalui analisis regresi linear sederhana diperoleh hasil $\mathrm{F}$ hitung $=11800,632$. Berdasarkan teori yang telah dikemukakan sebelumnya, maka untuk taraf signifikansi sebesar 0,05>0,000, jadi analisis regresi ini dapat digunakan untuk menilai variabel bebas memiliki pengaruh terhadap variabel terikat.

2. Berdasarkan krieteria uji hipotesis (uji t) untuk variabel bebas diperoleh nilai $t_{\text {hitung }}$ sebesar 108,631 > $t_{\text {tabel }} 2,016$, maka variabel Kompetensi Guru dalam menghadapi pembelajaran era milenial berpengaruh positif terhadap hasil belajar siswa di SMK Panca Budi 2 Medan Tahun Ajaran 2019-2020.

3. Berdasarkan hasil uji koefisien determinasi ( $\mathrm{R}$ Square) sebesar 0,996 yang mengandung pengertian bahwa pengaruh variabel bebas (Kompetensi Guru dalam menghadapi pembelajaran era milenial) terhadap variabel terikat (Hasil Belajar Siswa) adalah sebesar 99,6\%. 
Liabilities Jurnal Pendidikan Akuntansi

e-ISSN 2620-5866

Volume 2. No.3 Desember 2019 (201-212)

Doi 10.30596/liabilities.v2i3.3689

\section{Saran}

1. Bagi pihak sekolah

Melalui hasil penelitian diharapkan pendidik lebih menggali kemampuan kognitifnya untuk memvariasikan model pembelajaran konvensional dengan pembelajaran campuran (blended learning).

a) Berdasarkan hasil penelitian diharapkan pihak sekolah dapat memberikan akses dengan tidak terbatas agar guru dan peserta didik lebih mudah untuk melakukan pembelajaran secara virtual.

b) Pihak sekolah dapat menambah jaringan internet agar seluruh warga sekolah dapat mengakses pembelajaran dengan cepat.

2. Bagi Pihak Lain

Pada dasarnya penelitian ini sangat jauh dari kata sempurna, ada banyak kekurangan yang terjadi. Maka bagi pihak lain yang akan melakukan penelitian sejenis, hendaknya dapat memilih jumlah populasi dan sampel yang lebih banyak agar data yang diperoleh lebih teruji.

\section{DAFTAR PUSTAKA}

Abdullah, D. 2011. Potensi Teknologi Informasi dan Komunikasi dalam Peningkatan Mutu Pembelajaran di Kelas, (Online),(http://elearning. unimal. ac. id / upload / materi I peningkatan-tik guru.pdf), diakses tanggal 1 Juni 2013).

Hopkins, K.R. 2010. Teaching How to Learn in a What-to-Learn Culture. San Fransisco, CA: Jossey-Bass.

Indrayani, E. 2007. E-learning: Konsep, dan Strategi Pembelajaran di Era Digital (Implementasi pada Pendidikan Tinggi). Jurnal Ilmiah Visioner Tahun 2007.

Johan, R.C. 2010. Pembelajaran Berbasis Komputer, (Online), (http://kurtek.upi.edu/tik/?p=h akikat), diakses tanggal 1 Juni 2013).

Kusairi, S. 2011. Implementasi Blended Learning. Makalah (disajikan pada Seminar Nasional Blended Learning tanggal 13 November 2011 di Universitas Negeri Malang). 